\title{
Gracilibacter thermotolerans gen. nov., sp. nov., an anaerobic, thermotolerant bacterium from a constructed wetland receiving acid sulfate water
}

Correspondence
Juergen Wiegel
jwiegel@uga.edu

It is well known that various microbial communities are involved not only in the generation but also in the remediation of acid mine drainage. Most of the microorganisms isolated from mining environments are iron- and sulfur-oxidizing bacteria and sulfate-reducing bacteria. Although heterotrophic fermentative bacteria are closely associated with other microbial communities in acid mine drainage, little is known about their diversity and functions in such environments. For instance, heterotrophic fermentative bacteria can remove organic acids that can inhibit chemolithotrophic bacteria such as Leptospirillum ferrooxidans and Acidithiobacillus ferrooxidans (Johnson, 1998). Therefore, the generation of acid mine drainage can be facilitated by indigenous heterotrophic bacteria. Conversely, they also support sulfate- or metal-reducing bacteria by

\footnotetext{
Abbreviation: PLFA, phospholipid fatty acid.
}

The GenBank/EMBL/DDBJ accession numbers for five clones of the 16S rRNA gene sequences of strain JW/YJL-S1 ${ }^{\top}$ are DQ117465DQ117469. degrading biopolymers into monomers and fermentation products, which then serve as substrates, thus contributing to the bioremediation of acid mine drainage.

Here we report on a new isolate recovered from a constructed treatment wetland system receiving acid sulfate water. On the basis of the physiological and phylogenetic evidence presented, we propose a new genus, Gracilibacter, to accommodate this organism.

Strain JW/YJL-S1 ${ }^{\mathrm{T}}$ was isolated from an MPN (most probable number) tube inoculated with sediment from the upper layer of a constructed treatment wetland system. This wetland was receiving water from an acid sulfate runoff pond from a coal pile located at the Department of Energy's Savannah River Site near Aiken, SC, USA (Lee, 2005). The acid runoff pond water has a $\mathrm{pH}$ of $1 \cdot 6-3 \cdot 0$ and relatively high sulfate and ferric iron concentrations. The uppermost sediment in the constructed wetland was dominated by iron oxyhydroxide precipitates coating and replacing an organic substrate amended with limestone. The organic substrate 
used for the constructed treatment wetland was composed primarily of composted stable wastes and spent brewing grains mixed with local farmland soil from South Carolina (Thomas, 2003; Lee, 2005). Thus, no defined habitat can be given for the novel taxon described herein.

The isolate was routinely cultured in a carbonate-buffered basal medium (Widdel \& Bak, 1992) supplemented with $20 \mathrm{mM}$ acetate and $0 \cdot 1 \mathrm{mM}$ ferric citrate at $\mathrm{pH}_{25}{ }^{\circ} \mathrm{C} 6 \cdot 8$ (Wiegel, 1998) and $37^{\circ} \mathrm{C}$ under anaerobic conditions $\left(\begin{array}{ll}100 \% & \mathrm{~N}_{2}\end{array}\right)$ using a modified Hungate technique (Ljungdahl \& Wiegel, 1986). Single colonies were obtained from dilution rows in agar- $(1.5 \% \mathrm{w} / \mathrm{v})$ shake roll-tubes. To ensure that a culture was derived from a single cell, the isolate was purified by an additional five rounds of single colony isolation using the agar-shake roll-tube method (Ljungdahl \& Wiegel, 1986). Surface colonies of strain JW/YJL-S1 ${ }^{\mathrm{T}}$ appeared after 2-3 days and were less than $1 \mathrm{~mm}$ in diameter, circular to irregular, mostly translucent and filamentous. Cell morphology was observed via light microscopy (Olympus VANOX phase-contrast microscope) and electron microscopy (JEOL100CX transmission electron microscope). Vegetative cells in liquid culture were straight to curved, $0 \cdot 2-0 \cdot 4 \mu \mathrm{m}$ in diameter and $2 \cdot 0-7 \cdot 0 \mu \mathrm{m}$ in length (Fig. 1). Cells were either single or formed chains. Infrequently, cells up to $45 \mu \mathrm{m}$ in length were detected. No active motility was observed under phase-contrast microscopy when cells were grown in carbonate-buffered basal medium. However, retarded peritrichous flagella were observed under the electron microscope (Fig. 1a; negative staining). Motility was subsequently observed during growth in SIM agar medium (Cappuccino \& Sherman, 1987). No spores were detected either by microscopy or by heat treatment $\left(10 \mathrm{~min}\right.$ at $\left.80^{\circ} \mathrm{C}\right)$. Gram staining was performed according to standard procedures (Doetsch, 1981) and showed that cells from both the early exponential and the stationary growth phases in both media stained Gram-negative. Detailed results of morphological and physiological characterization are given in the genus and species descriptions below.

Using a temperature-gradient incubator (Scientific Industries, Inc.), the temperature range for growth was determined to be $25-54{ }^{\circ} \mathrm{C}$ with an optimum at $42 \cdot 5-46 \cdot 5^{\circ} \mathrm{C}$. No growth was detected at or below $20^{\circ} \mathrm{C}$ or at or above $58^{\circ} \mathrm{C}$. The $\mathrm{pH}$ range for growth was determined at $37^{\circ} \mathrm{C}$ in basal medium supplemented with $10 \mathrm{mM}$ each of MES, HEPES and TAPS. The $\mathrm{pH}_{25}{ }^{\circ} \mathrm{C}$ range for growth was $6 \cdot 0-8 \cdot 25$ with an optimum at $\mathrm{pH}_{25}{ }^{\circ} \mathrm{C} 6 \cdot 8-7 \cdot 75$. No growth was detected at or below $\mathrm{pH} 5 \cdot 7$ or at or above $\mathrm{pH} 8 \cdot 5$, suggesting that strain JW/YJL-S1 ${ }^{\mathrm{T}}$ originated not from the acid runoff but from the organic substrate of the constructed wetland. The salinity range for growth was $0-1.5 \%(\mathrm{w} / \mathrm{v})$ with an optimum at $0.5 \% \mathrm{NaCl}$ plus $\mathrm{KCl}$ at a ratio of $9: 1$; no growth was detected above $2 \%$ salts. The doubling time for strain JW/YJL-S1 ${ }^{\mathrm{T}}$ was $3 \cdot 1 \mathrm{~h}$ at $42{ }^{\circ} \mathrm{C}$ and $\mathrm{pH}_{25}{ }^{\circ} \mathrm{C} 6.5$ with $0.3 \%$ yeast extract as the substrate. The isolate required yeast extract for growth. For characterization tests, cultures were incubated for up to 20 days, with growth judged positive if the optical density (at $600 \mathrm{~nm}$ ) of the culture was twice that of a control culture containing only yeast extract $(0 \cdot 02 \%)$. Utilization of possible substrates $(0.2 \%, \mathrm{w} / \mathrm{v})$ was tested in the presence of $0.02 \%$ yeast extract. Strain JW/YJL-S1 ${ }^{\mathrm{T}}$ used Casamino acids, tryptone, peptone, maltose, sucrose, arabinose, fructose, galactose, glucose, mannose, xylose, mannitol and sorbitol as carbon and energy sources. No growth was observed with cellobiose, lactose, raffinose, ribose, trehalose, inositol, xylitol, acetate, lactate, pyruvate, methanol or carboxymethylcellulose $(1.0 \% \mathrm{w} / \mathrm{v}$, CMC $7 \mathrm{LT}$ or $7 \mathrm{M}$; Hercules) as carbon and energy sources. None of the following electron acceptors, tested in media containing $20 \mathrm{mM}$ lactate or $0 \cdot 1 \%$ yeast extracts, was utilized: fumarate, nitrate, sulfate, sulfite, thiosulfate, elemental sulfur, iron(III), anthraquinone 2,6disulfonate or manganese(IV) at concentrations of $20 \mathrm{mM}$ (sulfite was tested at $2 \mathrm{mM}$ ). Strain JW/YJL-S1 ${ }^{\mathrm{T}}$ showed positive growth on classical peptone-sugar media including

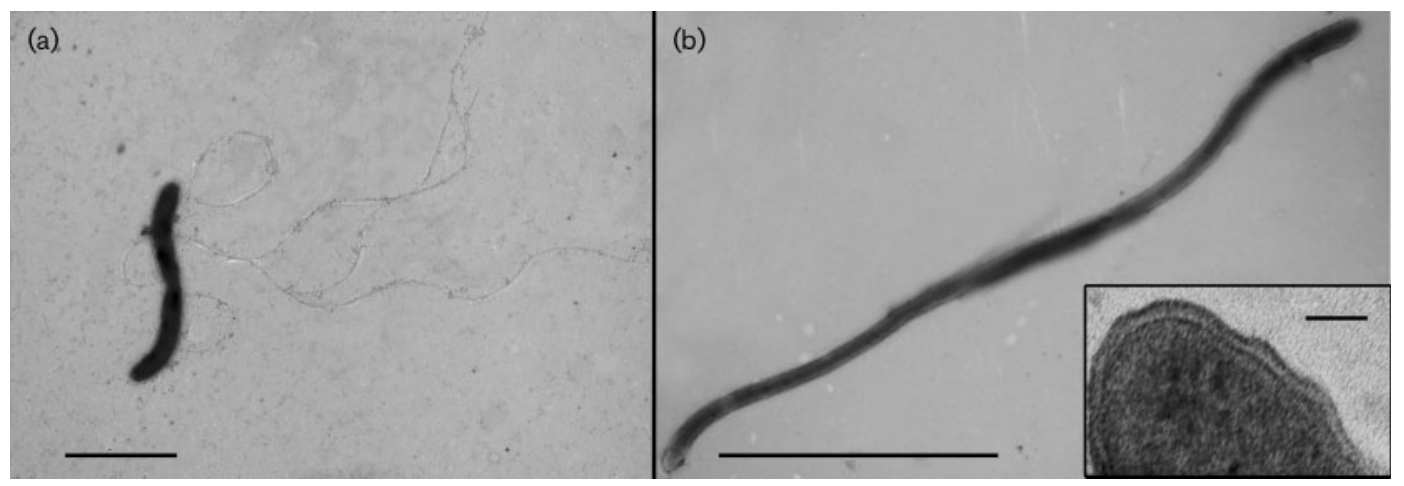

Fig. 1. Electron micrographs of cells of strain JW/YJL-S $1^{\top}$ showing retarded flagella (a) and the prototypical image of the cell line (b). The inset in (b) shows a thin section that matches a conventional thin section of a Gram-positive bacterium that has an $\mathrm{S}$ layer. Bars, $2 \mu \mathrm{m}(\mathrm{a}), 4 \mu \mathrm{m}$ (b) and $50 \mathrm{~nm}$ [inset in (b)]. 
peptone-yeast extract (PY), peptone-yeast extract-glucose (PYG), reinforced clostridial medium (RCM; Difco) and thioglycolate broth (Difco). Fermentation end products from $20 \mathrm{mM}$ glucose were analysed by HPLC with an Aminex-H87 column (Bio-Rad) and Beckman detector. The main organic fermentation end products were acetate, lactate and ethanol. Bacterial cell-membrane phospholipid fatty acids (PLFAs) were extracted and isolated from lyophilized cells. Total lipids were extracted, fractionated and saponified and then methylated to obtain fatty acid methyl esters of the phospholipids as described by Guckert et al. (1985). These were then analysed by using a capillary column $(30 \mathrm{~m} \mathrm{DB}-5$, $0.25 \mathrm{~mm}$ inner diameter) gas chromatograph (Agilent 6890 ) equipped with a flame-ionization detector and by using a gas chromatograph-mass spectrometer (Agilent $7972 \mathrm{MSD}$ ). Compounds were identified by comparison of retention times with a bacterial acid methyl ester standard (Supelco) and by analysis of the mass spectra data. The PLFA composition of strain JW/YJL-S1 ${ }^{\mathrm{T}}$ was dominated by branched-chain fatty acids (i15:0, a15:0, i16:0 and i17:0), which accounted for $44 \cdot 7 \%$ of the total PLFAs. Significant amounts of 16:0 (29.0\%) and small amounts of the unsaturated $16: 1,17: 1$ and $18: 1$ fatty acids $(5 \cdot 4,5 \cdot 4$ and $2 \cdot 5 \%$, respectively) were also present (Table 1 ). This profile is similar to that reported by O'Leary \& Wilkinson (1988) for closely related Gram-type positive bacteria. Antibiotic susceptibility was tested with ampicillin, chloramphenicol, erythromycin, rifampicin, streptomycin and tetracycline at concentrations of 10 and $100 \mu \mathrm{M}$. Strain JW/YJL-S1 ${ }^{\mathrm{T}}$ was resistant only to $10 \mu \mathrm{M}$ streptomycin. Biochemical properties of strain JW/YJL-S1 ${ }^{\mathrm{T}}$ were determined using the API ZYM system (bioMérieux). Enzyme assays of strain JW/ $\mathrm{YJL}-S 1^{\mathrm{T}}$ were positive for esterase, leucine arylamidase, acid phosphatase, naphthol-AS-BI-phosphohydrolase, $\beta$-galactosidase, $\alpha$-glucosidase and $\beta$-glucosidase. Strain JW/YJL-S1 ${ }^{\mathrm{T}}$ produced indole but not $\mathrm{H}_{2} \mathrm{~S}$ in SIM medium.

For phylogenetic and $\mathrm{G}+\mathrm{C}$ content analyses, DNA was extracted by using a DNeasy genomic DNA purification kit

Table 1. PLFA composition of strain JW/YJL-S1 ${ }^{\top}$

\begin{tabular}{|lc|}
\hline Identified component & Percentage of total \\
\hline $14: 0$ & $2 \cdot 3$ \\
i15:0 & $23 \cdot 8$ \\
a15:0 & $4 \cdot 9$ \\
$15: 0$ & $0 \cdot 5$ \\
i1 $6: 0$ & $0 \cdot 6$ \\
$16: 1$ & $5 \cdot 4$ \\
$16: 0$ & $29 \cdot 0$ \\
$17: 1$ & $5 \cdot 4$ \\
i17:0 & $15 \cdot 4$ \\
$17: 0$ & $2 \cdot 5$ \\
$18: 1 \omega 9 c$ & $1 \cdot 6$ \\
$18: 1$ & $0 \cdot 8$ \\
$18: 0$ & $3 \cdot 5$ \\
\hline
\end{tabular}

(Qiagen). The DNA G $+\mathrm{C}$ content was measured by HPLC as described by Mesbah et al. (1989) with the modification of Lee et al. (2005), using S1 nuclease (Invitrogen) and $0 \cdot 3 \mathrm{M}$ sodium acetate ( $\mathrm{pH} 5 \cdot 0)$. The $\mathrm{G}+\mathrm{C}$ content of the genomic DNA was $42 \cdot 8 \mathrm{~mol} \%$ (HPLC), the mean of four replicate analyses. 16S rRNA gene sequence analysis of strain $\mathrm{JW} / \mathrm{YJL}-\mathrm{S} 1^{\mathrm{T}}$ was carried out three times (yielding the same results) with a bacterial domain-specific primer set, 27 forward and 1492 reverse (Lane, 1991). PCR amplification was performed using the Easy-A high-fidelity PCR cloning enzyme (Stratagene) with 30 cycles of denaturation $\left(94^{\circ} \mathrm{C}\right.$, $30 \mathrm{~s})$, annealing $\left(58^{\circ} \mathrm{C}, 30 \mathrm{~s}\right)$ and extension $\left(72{ }^{\circ} \mathrm{C}, 1 \mathrm{~min}\right)$ after initial denaturation at $94^{\circ} \mathrm{C}$ for $3 \mathrm{~min}$. Final extension was for $7 \mathrm{~min}$ at $72{ }^{\circ} \mathrm{C}$. To check for possible heterogeneity of 16S rRNA genes, the PCR product of the 16S rRNA gene of strain JW/YJL-S1 ${ }^{\mathrm{T}}$ was cloned and transformed using the TOPO TA cloning kit (Invitrogen). Plasmid DNA was extracted using an Eppendorf FastPlasmid Mini kit (Brinkmann), amplified as described above, purified using the QIAquick PCR purification kit (Qiagen) and sequenced by Macrogen Inc. (Seoul, Korea). Similarities among partial sequences were determined using SEQUENCHER version 4.1.4 (Gene Codes). Retrieved 16S rRNA gene sequences were analysed using BLAST and then aligned manually using CLUSTAL X version 1.81 (Thompson et al., 1997) to create a multiple sequence alignment. A phylogenetic tree (Fig. 2) was inferred by the neighbour-joining method (Saitou \& Nei, 1987) using Jukes-Cantor distance corrections (Jukes \& Cantor, 1969), with the phylogenetic analysis package PHYLIP version 3.6a2.1 (Felsenstein, 2001). Five clones of the 16S rRNA gene (derived from a single cell colony) were sequenced and revealed the presence of polymorphism of the $16 \mathrm{~S}$ rRNA gene in strain JW/YJL-S1 ${ }^{\mathrm{T}}$. Four of the five sequenced clones grouped together with more than $99 \%$ similarity. The other sequenced clone showed about $2 \%$ divergence from the rest. When these $16 \mathrm{~S}$ rRNA gene sequences, containing 1550 bp [approximately positions - 107 to 1450 according to the Escherichia coli numbering scheme (GenBank accession no. X80725)], were compared using a BLASTN search against sequences in GenBank, they yielded the same correlations, i.e. that strain JW/YJL-S1 ${ }^{\mathrm{T}}$ was closely related to uncultured clones mostly obtained from methanogenic environments and to consortia including those from rice paddy-field microcosms (Chin et al., 1999; Hengstmann et al., 1999; Erkel et al., 2005), an oil reservoir (Grabowski et al., 2005), a uranium reduction enrichment plant (GenBank accession numbers DQ125504 and DQ125852) and methanogenic fermenter cultures degrading acetate (Shigematsu et al., 2003), propionate or butyrate (GenBank accession numbers AB221361, AB232817, AB248637, AB232818, AB248624 and AB248638). Using BLAST search, Clostridium pascui DSM $10365^{\mathrm{T}}$ (Clostridium cluster I based on the classification of Collins et al., 1994) had the most similar 16S rRNA gene sequence among bacteria with validly published names, with $93 \%$ similarity over the first $160 \mathrm{bp}, 92 \%$ for $1012 \mathrm{bp}$ and $96 \%$ for $54 \mathrm{bp}$. In an inferred phylogenetic tree, strain JW/YJL-S1 ${ }^{\mathrm{T}}$ was placed distantly between Collins' 


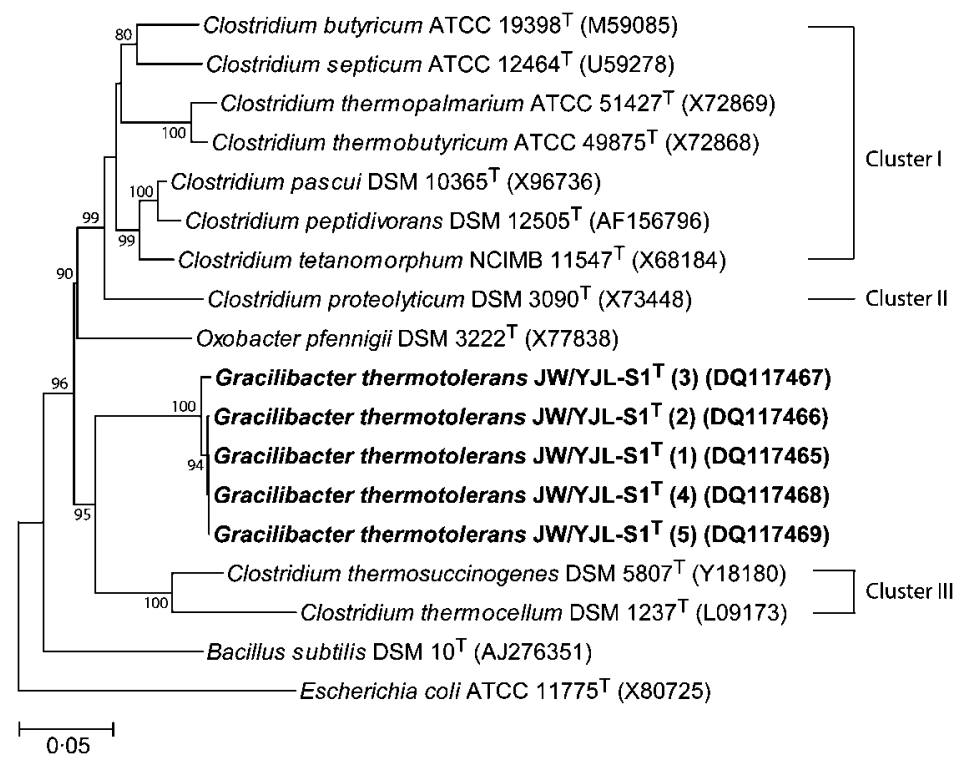

Fig. 2. Phylogenetic dendrogram based on $16 \mathrm{~S}$ rRNA gene sequences showing the position of strain JW/YJL-S1 ${ }^{\top}$ (bold type) among members of the family Clostridiaceae. The $16 \mathrm{~S}$ rRNA gene sequence data used correspond to E. coli ATCC $11775^{\top}$ nucleotide positions 1-1499. The tree was constructed using the neighbour-joining method with Jukes-Cantor distance corrections. Numbers at nodes represent bootstrap percentages (1000 replicates). Numbers in parentheses for strain JW/YJL-S1 ${ }^{\top}$ indicate numbering of different 16S rRNA gene sequences. Bar, $5 \mathrm{nt}$ substitutions per 100 nt.

Clostridium cluster I/II and III (Fig. 2) with Clostridium thermosuccinogenes as its closest neighbour. Note that in the recent emended description of the genus Clostridium (Wiegel et al., 2005), cluster II species such as Clostridium proteolyticum fall within cluster I and were classified as members of cluster I (the genus Clostridium sensu stricto), whereas cluster III members represent a new family. In addition to this phylogenetic evidence, strain JW/YJL-S1 ${ }^{\mathrm{T}}$ showed different physiological properties from members of Clostridium clusters I and III and from Oxobacter pfennigii. Whereas most Clostridium species and O. pfennigii form endospores, strain JW/YJL-S1 ${ }^{\mathrm{T}}$ showed no evidence of endospore formation. In addition, strain JW/YJL-S1 ${ }^{\mathrm{T}}$ was not cellulolytic, distinguishing it from Clostridium thermocellum and related cellulolytic species in cluster III; nor did it produce succinic acid or grow at elevated temperatures. Strain JW/YJL-S1 ${ }^{\mathrm{T}}$ was also metabolically more versatile than O. pfennigii. Furthermore, the DNA G $+\mathrm{C}$ content of strain JW/YJL-S1 ${ }^{\mathrm{T}}(42 \cdot 8 \mathrm{~mol} \%)$ is significantly higher than that of related clostridial species. Based on the polyphasic evidence provided here, JW/YJL-S1 ${ }^{\mathrm{T}}$ is proposed as the type strain of a novel species in a new genus, Gracilibacter thermotolerans gen. nov., sp. nov., belonging to the order Clostridiales (Garrity et al., 2004) but without assignment to a family.

\section{Description of Gracilibacter gen. nov.}

Gracilibacter (Gra.ci.li.bac'ter. L. adj. gracilis slender; N.L. masc. $n$. bacter equivalent of Gr. neut. n. baktron rod or staff; N.L. masc. n. Gracilibacter slender rod, referring to its cell shape).

A member of the low-G $+\mathrm{C}$ (about $43 \mathrm{~mol} \%$ ) Grampositive subphylum Bacillus-Clostridium. Specific habitat unknown. Anaerobic chemo-organotrophs. No spores observed. The type species is Gracilibacter thermotolerans.

\section{Description of Gracilibacter thermotolerans sp. nov.}

Gracilibacter thermotolerans (ther.mo.to'le.rans. Gr. n. thermê heat; L. pres. part. tolerans tolerating; N.L. part. adj. thermotolerans heat-tolerating).

Cells are straight to curved rods, $0 \cdot 2-0 \cdot 4 \mu \mathrm{m}$ in diameter and $2 \cdot 0-7 \cdot 0 \mu \mathrm{m}$ in length. Gram-type positive (Wiegel, 1981) but Gram staining negative at all growth phases. Autoplasts (L-shaped cells) occur infrequently during the late-stationary growth phase. Non-motile although retarded flagella (1-5 per cell) are present. PLFA profile is dominated by branched-chain fatty acids: i15:0, a15:0, i16:0 and i17:0. Temperature range for growth is $25-54^{\circ} \mathrm{C}$ (no growth at and below $20^{\circ} \mathrm{C}$ or at or above $58^{\circ} \mathrm{C}$ ), with an optimum at $42 \cdot 5-46 \cdot 5^{\circ} \mathrm{C}$. The $\mathrm{pH}_{25^{\circ} \mathrm{C}}$ range for growth is $6 \cdot 0-8 \cdot 25$ (no growth at and below $\mathrm{pH}_{25}{ }^{\circ} \mathrm{C} 5 \cdot 7$ or at or above $\left.\mathrm{pH}_{25}{ }^{\circ} \mathrm{C} 8 \cdot 5\right)$, with an optimum at $6 \cdot 8-7 \cdot 75$. The salinity range for growth is $0-1 \cdot 5 \%(\mathrm{w} / \mathrm{v})$, with an optimum at $0.5 \%$. In the presence of $0.02 \%$ yeast extract, Casamino acids, tryptone, peptone, maltose, sucrose, arabinose, fructose, galactose, glucose, mannose, xylose, mannitol and sorbitol serve as carbon and energy sources. The main organic fermentation end products from glucose are acetate, lactate and ethanol. No indication of growth on $\mathrm{H}_{2} / \mathrm{CO}_{2}(80: 20, \mathrm{v} / \mathrm{v})$ or the use of iron(III), nitrate, thiosulfate, elemental sulfur, sulfate, sulfite, $\mathrm{MnO}_{2}$ or fumarate as electron acceptors. Positive for esterase, leucine arylamidase, acid phosphatase, naphthol-AS-BI-phosphohydrolase, $\beta$-galactosidase, $\alpha$-glucosidase and $\beta$-glucosidase (API $\mathrm{ZYM})$. Indole is produced in SIM medium. Resistant to streptomycin $(10 \mu \mathrm{M})$. The $\mathrm{G}+\mathrm{C}$ content of the genomic DNA is $42 \cdot 8 \mathrm{~mol} \%$ (HPLC).

The type strain, JW/YJL-S1 ${ }^{\mathrm{T}}\left(=\mathrm{DSM} 17427^{\mathrm{T}}=\right.$ ATCC BAA$1219^{\mathrm{T}}$ ), was isolated from a constructed treatment wetland system at the Department of Energy's Savannah River Site, 
Aiken, SC, USA. The $16 \mathrm{~S}$ rRNA gene of the type and so far only strain exhibits the presence of polymorphism.

\section{Acknowledgements}

This research was partially supported by Financial Assistance Award Number DE-FC09-96SR18546 between the United States Department of Energy and the University of Georgia. We thank Robert C. Thomas for providing samples for the experiments and Jean P. Euzéby for his help with the nomenclature.

\section{References}

Cappuccino, J. G. \& Sherman, N. (1987). Microbiology: A Laboratory Manual, 2nd edn. Menlo Park, CA: Benjamin \& Cummins Publishing Co., Inc.

Chin, K.-J., Hahn, D., Hengstmann, U., Liesack, W. \& Janssen, P. H. (1999). Characterization and identification of numerically abundant culturable bacteria from the anoxic bulk soil of rice paddy microcosms. Appl Environ Microbiol 65, 5042-5049.

Collins, M. D., Lawson, P. A., Willems, A., Cordoba, J. J., FernandezGarayzabal, J., Garcia, P., Cai, J., Hippe, H. \& Farrow, J. A. E. (1994). The phylogeny of the genus Clostridium: proposal of five new genera and eleven new species combinations. Int J Syst Bacteriol 44, 812-826.

Doetsch, R. N. (1981). Determinative methods of light microscopy. In Manual of Methods for General Bacteriology, pp. 21-23. Edited by P. Gerhardt, R. G. E. Murray, R. N. Costilow, E. W. Nester, W. A. Wood, N. R. Krieg \& G. B. Philips. Washington, DC: American Society for Microbiology.

Erkel, C., Kemnitz, D., Kube, M., Ricke, P., Chin, K.-J., Dedysh, S., Reinhardt, R., Conrad, R. \& Liesack, W. (2005). Retrieval of first genome data for rice cluster I methanogens by a combination of cultivation and molecular techniques. FEMS Microbiol Ecol 53, 187-204.

Felsenstein, J. (2001). PHYLIP - Phylogeny Inference Package, version 3.6a2.1. Distributed by the author. Department of Genome Sciences, University of Washington, Seattle, USA.

Garrity, G. M., Bell, J. A. \& Lilburn, T. G. (2004). Taxonomic outline of the prokaryotes. In Bergey's Manual of Systematic Bacteriology, 2nd edn, release 5.0. New York: Springer. http://dx.doi.org/10.1007/ bergeysoutline

Grabowski, A., Nercessian, O., Fayolle, F., Blanchet, D. \& Jeanthon, C. (2005). Microbial diversity in production waters of a low-temperature biodegraded oil reservoir. FEMS Microbiol Ecol 54, 427-443.

Guckert, J. B., Antworth, C. P., Nichols, P. D. \& White, D. C. (1985). Phospholipid ester-linked fatty acid profiles as reproducible assays for changes in prokaryotic community structure of estuarine sediments. FEMS Microbiol Ecol (FEMS Microbiol Lett Special Issue) 31, 147-158.

Hengstmann, U., Chin, K.-J., Janssen, P. H. \& Liesack, W. (1999). Comparative phylogenetic assignment of environmental sequences of genes encoding 16S rRNA and numerically abundant culturable bacteria from an anoxic rice paddy soil. Appl Environ Microbiol 65, 5050-5058.
Johnson, D. B. (1998). Biodiversity and ecology of acidophilic microorganisms. FEMS Microbiol Ecol 27, 307-317.

Jukes, T. H. \& Cantor, C. R. (1969). Evolution of protein molecules. In Mammalian Protein Metabolism, vol. 3, pp. 21-132. Edited by H. N. Munro. New York: Academic Press.

Lane, D. J. (1991). 16S/23S rRNA sequencing. In Nucleic Acid Techniques in Bacterial Systematics, pp. 115-175. Edited by E. Stackebrandt \& M. Goodfellow. New York: Wiley.

Lee, Y. J. (2005). Microbial diversity in a constructed wetland system for treatment of acid sulfate water. $\mathrm{PhD}$ thesis, University of Georgia, Athens, GA, USA.

Lee, Y. J., Wagner, I. D., Brice, M. E., Kevbrin, V. V., Mills, G. L., Romanek, C. S. \& Wiegel, J. (2005). Thermosediminibacter oceani gen. nov., sp. nov. and Thermosediminibacter litoriperuensis sp. nov., new anaerobic thermophilic bacteria isolated from Peru Margin. Extremophiles 9, 375-383.

Ljungdahl, L. G. \& Wiegel, J. (1986). Anaerobic fermentations. In Manual of Industrial Microbiology and Biotechnology, pp. 84-96. Edited by A. L. Demain \& N. A. Solomon. Washington, DC: American Society for Microbiology.

Mesbah, M., Premachandran, U. \& Whitman, W. B. (1989). Precise measurement of the $\mathrm{G}+\mathrm{C}$ content of deoxyribonucleic acid by highperformance liquid chromatography. Int J Syst Bacteriol 39, 159-167.

O'Leary, W. M. \& Wilkinson, S. G. (1988). Gram-positive bacteria. In Microbial Lipids, vol. 1, pp. 117-201. Edited by C. Ratledge \& S. G. Wilkinson. New York: Academic Press.

Saitou, N. \& Nei, M. (1987). The neighbor-joining method: a new method for reconstructing phylogenetic trees. Mol Biol Evol 4, 406-425.

Shigematsu, T., Tang, Y., Kawaguchi, H., Ninomiya, K., Kijima, J., Kobayashi, T., Morimura, S. \& Kida, K. (2003). Effect of dilution rate on structure of a mesophilic acetate-degrading methanogenic community during continuous cultivation. J Biosci Bioeng 96, 547-558.

Thomas, R. C. (2003). Passive treatment of low $\mathrm{pH}$, ferric irondominated acid rock drainage. $\mathrm{PhD}$ thesis, University of Georgia, Athens, GA, USA.

Thompson, J. D., Gibson, T. J., Plewniak, F., Jeanmougin, F. \& Higgins, D. G. (1997). The CLUSTAL_X windows interface: flexible strategies for multiple sequence alignment aided by quality analysis tools. Nucleic Acids Res 25, 4876-4882.

Widdel, F. \& Bak, F. (1992). Gram-negative mesophilic sulfatereducing bacteria. In The Prokaryotes, 2nd edn, vol. 4, pp. 33523378. Edited by A. Balows, H. G. Trüper, M. Dworkin, W. Harder \& K. H. Schleifer. New York: Springer.

Wiegel, J. (1981). Distinction between the Gram reaction and the Gram type of bacteria. Int J Syst Bacteriol 31, 88.

Wiegel, J. (1998). Anaerobic alkali-thermophiles, a novel group of extremophiles. Extremophiles 2, 257-267.

Wiegel, J., Tanner, R. \& Rainey, F. A. (2005). An introduction to the family Clostridiaceae. In The Prokaryotes. An Evolving Electronic Resource for the Microbiological Community, release 3.20. New York: Springer. http://141.150.157.117:8080/prokPUB/metadata/releases/ 3.20.htm\# 